\title{
Klinik Uygulamalarda Düşük Glisemik ve/veya Besin İnsülin İndeksli Beslenme Yaklaşımları
}

\author{
Low Glycemic Index and/or Food Insulin Index Approaches in Clinical Practice
}

\section{Zeynep Caferoğlư ${ }^{1}$, Hülya Gökmen Özel ${ }^{2}$}

Geliş tarihi/Received: 06.07.2017 • Kabul tarihi/Accepted: 03.03.2018

\section{ÖZET}

Obezite, diyabet ve kalp-damar hastalıkları gibi yaşam tarzıyla ilişkili kronik hastalıkların postprandiyal glisemi ve insülinemi ile ilişkisi bilinmektedir. Bu nedenle, araştırmacılar postprandiyal glisemi ve insülinemiyi kontrol altına alabilecek çeşitli yöntem arayışlarına girmiş ve yeni kavramlar geliştirmişlerdir. Bu kavramlardan en önemlileri 1981 yılında ilk kez tanımlanan glisemik indeks iken, diğeri 1997 yılında ortaya atılan besin insülin indeksidir. Glisemik indeks (GI), karbonhidrat içeren besinlerin kan glukozunu yükseltme potansiyelini göstermektedir. Besin insülin indeksi (İI) ise sadece karbonhidrat içeren besinlerin değil, tüketilen tüm besinlerin insülin düzeyi üzerine etkilerini değerlendirmekte ve böylece protein ve yağların olası etkilerini de göz önünde bulundurmaktadır. Günlük diyette daha çok düşük Gİ’li ve/veya İ̉’li besinler tercih edilerek uzun dönemde yaşam tarzı ile ilişkili kronik hastalıklara yakalanma riski azaltılabilir. Aynı zamanda, yapılan çalışmalarda düşük GI’li ve/veya İI’li öğünlerin kısa dönem olumlu etkileri olabileceği de gösterilmiştir. Düşük Gİ’li ve/veya İI’li ögün tüketimi sonrası, yüksek Gİli ve/veya İI’li öğüne göre postprandiyal hiperglisemi ve hiperinsülinemi oluşumunun önlenebileceği ve açlık hissinin azaltılıp, doygunluğu arttırarak iştahın kontrol altına alınabileceği önerilmektedir. Bu nedenle, düşük Gİli ve/veya İI’li diyetlerin obezite ve diyabet tedavisinde yararlı olabileceğine işaret edilmektedir. Günümüzde, sağlıklı bir yaşam için fiziksel aktivite ve yeterli-dengeli beslenmenin yanısıra tüketilen besinlerin kalitesi de önem kazanmaktadır. Besinin Gİ ve İİ değeri besin kalitesini değerlendirmek amacıyla kullanılabilecek kriterler arasında yer almaktadir.

Anahtar kelimeler: Glisemik indeks, besin insülin indeksi, diyet, beslenme

\begin{abstract}
Lifestyle-related chronic diseases such as obesity, diabetes and cardiovascular diseases are known to be associated with postprandial glycemia and insulinemia. For this reason, researchers have sought out various methods that can control postprandial glycemia and insulinemia and have developed new concepts. The most important of these concepts is the glycemic index, which was first described in 1981, and the other is the food insulin index, introduced in 1997. The glycemic index (GI) shows the blood glucose raising potential of carbohydrate-containing foods. The food insulin index (FII) assesses not only the carbohydrate-containing foods but also the effects of all consumed foods on the insulin level, thus taking into account possible effects of proteins and fats. The risk of chronic life-style related diseases in the long term can be reduced by preferring foods with lower GI and/or FII in the daily diet. It has also been shown in the conducted studies that low GI and/ or FII meals may have short-term positive effects. It is suggested that the postprandial hyperglycemia and hyperinsulinemia
\end{abstract}

1. İletişim/Correspondence: Erciyes Üniversitesi, Sağlık Bilimleri Fakültesi, Beslenme ve Diyetetik Bölümü, Kayseri, Türkiye - E-posta: zeynepcaferoglu@gmail.com (ㄱ https://orcid.org/0000-0002-7226-5636
2. Hacettepe Üniversitesi, Sağlık Bilimleri Fakültesi, Beslenme ve Diyetetik Bölümü, Ankara, Türkiye

(ㄱ https://orcid.org/0000-0002-8282-6468 
can be prevented and the appetite can be controlled by reducing hunger feeling, increasing satiety after low GI and/or FII meal consumption than after high GI and/or FII meal. In this respect, it is pointed out that low GI and/or FII diets may be useful in the treatment of obesity and diabetes. Recently, the quality of the consumed food as well as physical activity and adequate-balanced nutrition become important for a healthy life. The GI and II indices of food are also among the criteria that can be used to assess its quality.

Keywords: Glycemic index, food insulin index, diet, nutrition

\section{Gíriş}

Postprandiyal hiperglisemi ve hiperinsülinemi, yaşam tarzıyla ilişkili kronik hastalıkların (tip 2 diyabet, koroner kalp hastalıkları vb.) gelişiminde yer alan etmenlerdendir. Karbonhidratlar, kan glukoz düzeyini doğrudan arttıran en önemli besin ögesidir ve insülin salgısının temel belirleyicisidir. Bununla birlikte, sadece diyet enerjisinin karbonhidratlardan gelen oranı hastalık riski ile hem pozitif hem de negatif yönde ilişkili değildir. Aksine, elde edilen kanıtların birçoğu diyet posası ve karbonhidrat kaynaklarının da önemli etkileri olduğunu göstermektedir (1). Bu konu ile ilgili ilk çalışma 1981 yllında yapılmış ve besinin formuna, diyet posası içeriğine ve besindeki karbonhidrat türüne göre postprandiyal gliseminin etkilendiği gösterilmiştir (2). Karbonhidrat içeren besinlerin postprandiyal glisemi üzerindeki etkilerine göre sinıflandırılması ve değerlendirilmesi için glisemik indeks kavramı ilk kez Jenkins ve arkadaşları tarafindan kullanılmıştır (3). FAO/ WHO Uzmanlar Komitesi ise 1997 yllında, glisemik indeksin sağlığın korunmasında ve bazı hastalıkların tedavisinde kullanılabilecek en uygun karbonhidrat kaynaklarının seçimi için yararlanılabilecek bir yöntem olduğunu bildirmiştir (4).

Glisemik indeks (Gİ), aynı birey tarafindan tüketilen ve $50 \mathrm{~g}$ karbonhidrat içeren bir test besininin 2 saat içerisinde oluşturduğu kan glukoz artış alanının, aynı miktarda karbonhidrat içeren referans besinin (glukoz veya beyaz ekmek) oluşturduğu kan glukoz artış alanına göre yüzde olarak ifadesi anlamına gelen bir kavramdır (2,5). Glisemik yük (GY) ise ilk kez 1997 yılında, bir porsiyon besin tarafindan oluşturulan glukoz yanıtın ve insülin gereksinmesinin göstergesi olarak kullanılmıştır (1). Hem karbonhidrat içeren besinin kalitesini (glisemik indeks) hem de tüketilen miktarını (ağırlığını) birlikte değerlendiren bir kavram olan GY, besinin postprandiyal insülin salgısı üzerine etkisini gösteren iyi bir ölçüt olarak kabul edilmektedir. Bu yüzden, besinlerin insülinojenik etkisini tahmin etmekte yaygin olarak Gİ ve/veya GY’ten yararlanılmaktadır $(2,5)$. Ancak, insülin yanıtı her zaman kan glukoz yanıtı ile orantılı değildir. Karbonhidratlar insülin salgısının temel uyaranı olmasına rağmen, diğer besin ögeleri de bu süreçte rol oynamaktadır. Protein ya da yağdan zengin besinler belirgin insülin yanıta neden olabilirler ve proteinler, karbonhidrat içeren besinlerle birlikte sinerjik etki göstererek insülin yanıtını arttırabilirler (5).

$\mathrm{Bu}$ derleme yazının amacl, klinik uygulamalarda kullanılabilecek düşük glisemik indeksli ve/veya besin insülin indeksli yaklaşımların sağlık üzerine etkilerine ilişkin olası mekanizmaları incelemek ve kısa dönem postprandiyal glisemi, insülinemi ve iştah üzerine etkilerini göstermektir.

\section{Besin İnsülin İndeksi}

Farklı türden besinlerin posprandiyal insülin yanıtlarını sistematik olarak değerlendirebilmek amacıyla, Holt ve arkadaşları (6) tarafından 1997 yılında insülinemik indeks kavramı geliştirilmiştir. Besin insülin indeksi (İi), referans besinin (glukoz veya beyaz ekmek) izoenerjik porsiyonu ile karşılaştırıldığında test besinine postprandiyal insülin yanıtı doğrudan ölçmektedir. Karşılaştırma ölçütü olarak GI için karbonhidratların kullanılmasının aksine enerji kullanıldığı için, İ̇ kavramı karbonhidrat içeriği az olan ya da hiç olmayan besinlerin de test edilmesine olanak sağlamaktadır (5). Hesaplama 
yapılırken, test besinin $1000 \mathrm{~kJ}$ (239 kkal) enerji içeren porsiyonu tüketildikten sonraki iki saat boyunca elde edilen insülinemik yanıtı (eğri altında kalan alan) referans besinin insülinemik yanıtına bölünmektedir (7). Ayrıca, diyetin ortalama insülin yükü (İY) kaydedilen tüm besinlerin insülin indeksi, enerji içeriği ve tüketim sıklığının toplamıyla hesaplanabilir ve bu sayede tüm diyetin insülin gereksinmesi tahmin edilebilir (8). Günümüze kadar, 121 besinin ve 13 karışık öğünün İi değerleri belirlenmiştir (1). Yüksek İI'li besinlere verilebilecek örnekler firında pişirilmiş kuru fasulye (120), yoğurt (115) ve misır gevrekleri (75) iken, orta İI değeri için havuç (çiğ, 42), mısır (53) ve düşük İI için süt (33), alkollü içecekler (beyaz şarap, 3) ve ceviz (7)'dir (5).

\section{Glisemik İndeks ile İlişkili Olası Mekanizmalar}

Düşük Gİ'li besinlerin tüketilmesi ile oluşan metabolik değişikliklerin altında yatan mekanizmalar tam olarak aydınlatılamamıştır (9). Besinlerin glisemik yanıt miktarında azalmaya neden olarak düşük GI'li olarak sınıflandırılmasını sağlayan etmenler arasında çözünür posa, amiloz, dirençli nişasta, fruktoz, protein ve yağ içeriği yer almaktadır. Çözünür posa ve pH midenin daha yavaş boşalmasını sağlamaktadır. Dirençli nişasta varlığında ise enzimlerin biyoaktivitesi azalmakta ve bu sayede ortaya çıan ve emilen glukoz miktarı da azalmaktadır (10). Diğer taraftan, yüksek Gİli besinlerin tüketimi glukoz artışı ve bunun sonucu olarak da insülin salgısında artış ve glukagonun azalması gibi glukoz homeostazisinin bozulmasina neden olan bir dizi hormonal olaya neden olabilmektedir. İnsülin varlığı glukoneogenezis ve lipolizisin aktive olmasına neden olacak ve yolaklarının kontrolünü sağlayacaktır. Sonuç olarak, kısa bir süre sonra glukozda yaşanan hızlı düşüş açlık duygusunun tekrar oluşmasına, doygunluğun azalmasına fazla enerji alımına yol açacaktır $(9,10)$. Ayrıca, hiperglisemi serbest yağ asit düzeyindeki artış ile ilişkilidir ve reaktif oksijen ve nitrojen türlerindeki artış aracılığıyla oksidatif stresi indüklemektedir. Oksidatif stres ise sitokin salınımındaki artış vasıtasıyla düşük derecede sistemik inflamasyon oluşumuna aracılık etmekte ve tip 2 diyabet ve metabolik sendrom patofizyolojisine katkıda bulunmaktadir. Postprandiyal hipergliseminin normal aralıklarda olsa dahi oksidatif stresi destekleyebileceği ve aterosklerozisin temelinde yatan süreci kötüleştirebileceği bir gerçektir (9).

On sağlıklı genç ile yapılan çalışmada, yüksek GI'li karbonhidrat kaynağı olan beyaz ekmeğin düşük GI'li karbonhidrat kaynağı olarak kullanılan makarna ile karşılaştırıldığında nükleer etmen kb aktivasyonundaki üç kat artışla inflamatuvar süreci daha kötü hale getirdiği kanıtlanmıştır (11). Düşük Gİli diyetler kan glukoz ve insülin düzeyini azaltır, daha fazla yağ oksidasyonuna katkı sağlar, lipojenezisi azaltır ve doygunluğu arttırırlar (9). Ayrıca, düşük GY'lü diyetlerin yüksek GY'lü diyetlere göre daha fazla yağ ve protein içeriğine sahip olduğu da unutulmamalıdır. Protein ve yağlar duodenum ve jejunumun I hücrelerinden kolesistokinin salgısını uyarırlar, salınan kolastokinin pilorik sfinkterdeki kendi reseptörlerini aktive eder ve sfinkterin kontraksiyonunu güçlendirir. Sonuç olarak, bireyin midesi daha geç boşalacak ve açlık ertelenecektir (10).

Enerji homeostazisinde, metabolik ve hemodinamik etkileri olan birçok hormon beyin-bağırsak-pankreaskaraciğer aksisinde yer almaktadır. Şekil 1'de yüksek GI'li besin tüketiminin olası sonuçları özetlenmiştir (9).

Akşam yemeklerinde düşük GI'li besinler tüketen sağlıklı yetişkinler ile yapılan bir çalışmada, glukoz yanitının kolonik fermentasyon, plazma glukagonbenzeri peptid-1 (Glucagon-Like Peptide-1, GLP-1) ve kahvaltıdaki doygunluk ile ters yönde korelasyon gösterdiği saptanmış ve artmış kolonik fermentasyonla ilişkili olarak inkretin hormonlarındaki artışın düşük GI'li besin tüketiminden sonra gözlenen doygunluktaki artışı açıklayabileceği gösterilmiştir (12). Deney hayvanları ile yapılan çalışmalarda ise yüksek Gİli besinlerin posprandiyal glukoz ve insülin düzeylerinde hızla artışa, adiponektin düzeyinde düşüşe, artmış vücut yağı ve azalmış yağsız doku kütlesine neden olduğu bulunmuştur $(13,14)$. 


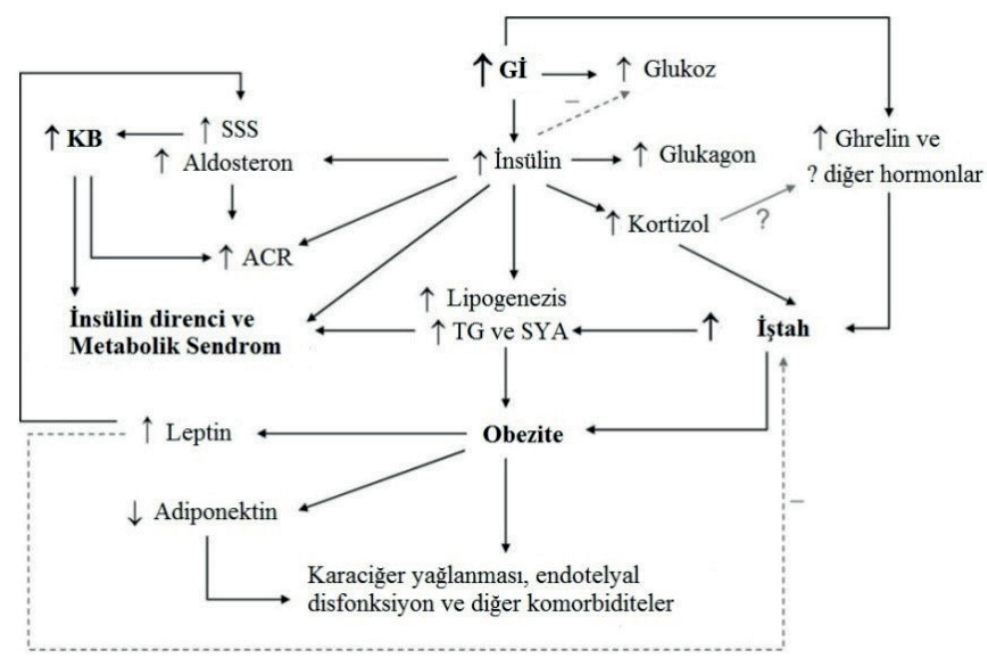

Şekil 1. Glisemik indeks ile ilişkili olası mekanizmalar

(SSS: sempatik sinir sistemi, ACR: idrar albümin-kreatinin oranı, KB: kan basınc, SYA: serbest yăg asitleri, TG: trigliserit, kalın çizgiler: destekleme ya da aktivasyon, negatif sinyalli kesik çizgiler: supresyon) (9)

\section{Besin İnsülin İndeksi ile İlişkili Olası Mekanizmalar}

Besinlerin İİ değerleri doğrudan insülin yanıtlarına dayandığı için, obezitede olduğu gibi insülin maruziyetine bağlı olarak ortaya çıktığı düşünülen durumların değerlendirilmesinde kullanılmasının Gİden daha yararlı olacağı düşünülmektedir (5). Vücut yağ miktarındaki artış için yüksek postprandiyal insülin düzeylerinin mekanistik rolü, besin ögelerinin kaslarda oksidasyondan uzaklaşmaya ve yağ dokusunda depolanmaya doğru tercihli yönelimine dayandırılabilir (15). Bu doğrultuda, yetişkinlerde yapılan bir çalışmada, 30. dakikadaki postprandiyal hiperinsülineminin ağırlık kazanımı için güçlü bir belirleyici olduğu ve altı yılda bel çevresini değiştirdiği rapor edilmiştir (16). Ayrıca, yüksek insülin ve düşük plazma glukagon düzeyleri hepatik glukoz üretimini sınırlandırabilir ve lipolizisi baskılayabilir. Böylece, uzun dönemde, beta hücreleri üzerindeki sürekli devam eden yüksek postprandiyal talep insülin duyarlılığını azaltabilir ve yağ dokusunun artışını destekleyebilir (15).

Yüksek İI/IYY'lü diyetlerin artmış vücut yağ oranına katkıda bulunabileceği bir diğer olası mekanizma, insülin ve insülin benzeri büyüme faktörü-1 (Insulinlike Growth Factor-1, IGF-1) salgisının çaprazstimülasyonu aracılığıyla gerçekleşebilir (15).
Adipozit öncül hücre kültürlerinin kullanıldığı in vitro çalışmalarda $(15,17)$, artmış IGF-1 düzeylerinin preadipozit proliferasyonu üzerinde uyarıcı etkisinin olduğu ve bu sayede vücut yağ depolanmasına katkıda bulunabileceği bulunmuştur. Aynı zamanda, IGF-1 preadipozit ve adipozitlerde hücresel glukoz alımını uyarır, lipojenezisi arttırır ve adipozitlerde lipolizisi baskılar (15).

\section{Öğünün Glisemik İndeksinin Postprandiyal Glukoz ve İnsülin Yanıt Üzerine Etkileri}

Öğünün Gİ/GY'ü ile kan glukoz ve insülin düzeyleri arasındaki ilişkiyi inceleyen çalışmaların sonuçları tutarlılık göstermekte olup, tamamı olmasa da (1821) büyük çoğunluğunda yüksek Gí/GY’lü öğününün artmış postprandiyal glukoz ve insülin yanıta neden olabileceği gösterilmiştir (22-36). Yapılan çalışmalarda daha çok öğün Gİinin etkileri araştırılmış ve hem sağlıklı (22-24) hem de fazla kilolu/obez (25-27) bireylerde, yüksek Gİli öğün sonrası glukoz ve insülin eğri altı alanlarının, düşük Gİ'li öğüne göre daha fazla olduğu sonucuna ulaşılmıştır. Öğün GY'ünün postprandiyal yanıt üzerine etkilerinin incelendiği çalışmalarda da benzer sonuçlar elde edilmiş ve yüksek GY’lü öğünün hem normal ağırlıktaki hem de fazla kilolu bireylerde artmış glukoz ve insülin yanıta 
neden olduğu gösterilmiştir (30-32,37).

\section{Öğünün İnsülin İndeksinin Postprandiyal Glukoz ve İnsülin Yanıt Üzerine Etkileri}

Öğünün İİ'inin postprandiyal glukoz ve insülin yanıt üzerine etkilerini inceleyen literatürdeki ilk ve tek çalışma, Bell ve arkadaşları (38) tarafindan 2015 yılında yayınlanmıştır. Sağlıklı ve tip 2 diyabetli yetişkinlerin dahil edildiği bu çalışmada enerji, makro besin ögeleri ve Gİ değerleri aynı, İI değerleri farklı olan iki test öğünü hazırlanmıştır. Çalışma sonucunda, iki öğünün postprandiyal glukoz yanıtları benzer bulunurken, yüksek İI'li öğüne klyasla düşük İI'li öğün sonrası insülin yanıtın sağlıklı bireylerde $\% 53$ ve tip 2 diyabetlilerde \%41 daha az olduğu belirtilmiştir (38). Literatürde yapılmış başka bir çalışmaya rastlanmaması, bu konunun araştırmaya açık olduğunu ve daha fazla çalışmaya gereksinme olduğunu göstermektedir.

\section{Öğünün Glisemik İndeksinin İştah Üzerine Etkileri}

Düşük Gİ/GY'lü öğünlerin postprandiyalglisemi ve insülinemideki dalgalanmaları en aza indirebileceği ve bu sayede açlığı ve ad libitum besin alımını azaltıp, doygunluğu arttırarak akut dönemde iştah üzerine olumlu etkiler sağlayabileceği düşünülmektedir (39-41). İspanya'da yürütülen GLYNDIET çalışması kapsamında obez yetişkinlerden elde edilen sonuçlar incelendiğinde, düşük Gİli öğün sonrası açlık skoru yüksek GI'li öğüne göre daha düşük bulunurken, doygunluk skorları arasında fark saptanmamıştır (42). Fazla kilolu ve obez yetişkinlerle yapılan farklı çalışmalarda ise düşük Gİli ögünün azalmış açlık (27) ve artmış doygunluk (43) skoruyla ilişkili olduğu gösterilmiştir. Benzer şekilde, öğün GY'ünün iştah üzerine etkilerini araştıran bir çalışmada da düşük GY’lü diyet sonrası tokluk ve doygunluğun arttığı ve yeme isteğinin azaldığı saptanmıştır (44). Bununla birlikte, fazla kilolu olan Danimarkalı yetişkinler ile yürütülen bir çalışmada öğün sonrası açlık ve doygunluk skorlarının düşük ve yüksek Gíli ögünler arasında herhangi bir farklılık göstermediği belirtilmiştir (19). Öğün Gİ'inin iştahı etkilemeği sonucuna ulaşan, sağlıklı $(45,46)$ ve obez $(18,26)$ yetişkinlerde yapılmış farklı çalışmalar da mevcuttur.

\section{Öğünün İnsülin İndeksinin İştah Üzerine Etkileri}

Öğünün İİ'inin iştah üzerine etkilerini inceleyen herhangi bir çalışmaya literatürde rastlanmamış olup, tek besinin İI'inin etkilerine ilişkin veriler $(3,47-49)$ ise oldukça sınırlıdır. Farklı çavdar ekmekleri ile yapılan bir çalışmada, test besinin İI'i arttıkça öğün sonrası yeme isteğinin de arttığı, ancak hissedilen açlık veya tokluk ile ilişki bulunamadığı belirtilmiştir (47). Farklı ekmek türleri ile yapılan diğer çalışmada ise İI ile subjektif olarak değerlendirilen iştah parametreleri arasında herhangi bir ilişki saptanmamıştır. Bununla birlikte, besin İI'indeki artışı ad libitum enerji alımının artmasına neden olduğu bulunmuştur. Ayrıca, artmış İI değerlerinin tokluk hormonları olan GLP-1 ve peptid YY düzeylerindeki artış ile ilişkili olduğu da gösterilmiştir (49). Öğünün İİ'inin açlık, doygunluk gibi iştah parametreleri ve ad libitum besin alımı üzerine etkilerini inceleyen herhangi bir çalışmaya literatürde rastlanmamış olması, bu konudaki soruları yanıtsız bırakmaktadır. Bu nedenle, öğünün İI'inin iştah üzerine etkilerini belirlemek amacıyla yürütülecekrandomize klinik çalışmalara gereksinme vardır.

\section{Öğünün Glisemik ve İnsülin İndeks Değerlerinin} Hesaplanması

Öğünün toplam Gİ/GY ve İI/IY miktarları, Bao ve arkadaşları (1) tarafindan 2011 yılında paylaşılan 121 besinin Gİ ve İİ değerleri (Tablo 1) kullanılarak aşağıdaki formüller $(1,5,7)$ ile hesaplanabilmektedir:

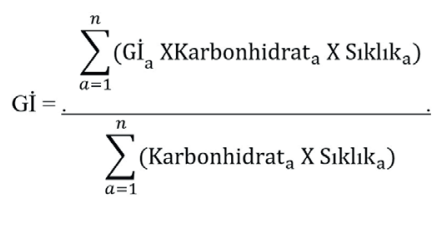

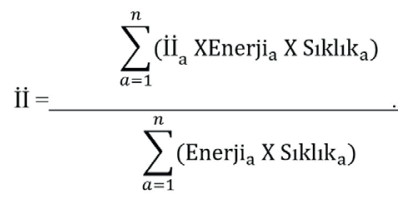

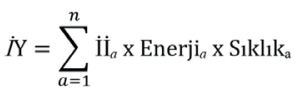


Tablo 1. Besinlerin makro besin ögesi bileşimleri, Gİ ve İİ değerleri (1)

\begin{tabular}{|c|c|c|c|c|c|c|}
\hline Besinler & Ağırlık (g veya mL) & Protein (g) & Yağ (g) & Sin CHO (g) & Gí & İI \\
\hline \multicolumn{7}{|l|}{ Referans besin } \\
\hline Glukoz & 59 & 0 & 0 & 59 & 100 & 100 \\
\hline \multicolumn{7}{|l|}{ Süt ve ürünleri } \\
\hline Süt (tam yağlı) & 368 & 11 & 14 & 17 & 31 & 24 \\
\hline Süt (\%1 yağll) & 558 & 20 & 6 & 27 & 29 & 34 \\
\hline Yoğurt (az yağlı, çilekli) & 260 & 12 & 5 & 38 & 31 & 84 \\
\hline Kaşar peyniri & 59 & 15 & 21 & 0 & 0 & 33 \\
\hline Kaşar peyniri (\%93 yağsız) & 119 & 41 & 8 & 1 & 0 & 20 \\
\hline Süzme peynir /lor peyniri /çökelek peyniri (yağı azaltılmış) & 234 & 29 & 10 & 7 & 10 & 40 \\
\hline Süzme peynir /lor peyniri /çökelek peyniri (az yağlı) & 264 & 30 & 6 & 16 & 10 & 52 \\
\hline Krem/eritme peynir & 68 & 6 & 24 & 3 & 0 & 18 \\
\hline Dondurma (vanilyalı) & 120 & 5 & 13 & 26 & 50 & 65 \\
\hline Dondurma (vanilyalı, az yağlı) & 185 & 6 & 7 & 44 & 43 & 69 \\
\hline \multicolumn{7}{|l|}{ Kahvaltılık gevrekler } \\
\hline Mısır gevreği (Cornflakes) & 67 & 5 & 0 & 55 & 81 & 82 \\
\hline Pirinç patlağ & 62 & 4 & 0 & 54 & 88 & 94 \\
\hline Tahıl gevreği (Special K) & 63 & 13 & 1 & 44 & 69 & 86 \\
\hline Tam buğday gevreği (All-Bran) & 76 & 7 & 2 & 47 & 60 & 55 \\
\hline \%100 doğal tahıl gevreği (yulaf, bal, üzümlü) & 55 & 6 & 9 & 35 & 44 & 41 \\
\hline Müsli bar & 63 & 11 & 5 & 37 & 56 & 34 \\
\hline \multicolumn{7}{|l|}{ Meyve ve meyve suları } \\
\hline Elma & 435 & 1 & 0 & 58 & 36 & 43 \\
\hline Portakal & 625 & 7 & 1 & 51 & 42 & 44 \\
\hline Muz & 279 & 3 & 0 & 56 & 52 & 59 \\
\hline Kavun & 714 & 5 & 2 & 46 & 62 & 93 \\
\hline Siyah üzüm & 395 & 1 & 0 & 57 & 50 & 60 \\
\hline Kuru üzüm (çekirdeksiz) & 72 & 2 & 1 & 56 & 64 & 31 \\
\hline Avokado & 112 & 2 & 25 & 0 & 0 & 4 \\
\hline Şeftali (konserve, şurupta) & 346 & 1 & 2 & 56 & 58 & 65 \\
\hline Seftali (konserve, kendi suyunda) & 485 & 2 & $\overline{1}$ & 55 & 40 & 54 \\
\hline Ahududu reçeli & 88 & 0 & 0 & 59 & 51 & 62 \\
\hline Portakal suyu (konsantre) & 625 & 3 & 0 & 53 & 53 & 55 \\
\hline Elma suyu & 588 & 0 & 0 & 59 & 39 & 47 \\
\hline \multicolumn{7}{|l|}{ Sebzeler } \\
\hline Havuç suyu (taze sıkılmış) & 762 & 6 & 1 & 41 & 43 & 41 \\
\hline Misır (dondurulmuş) & 222 & 6 & 3 & 43 & 47 & 39 \\
\hline Domates (makarna sosu) & 445 & 6 & 8 & 38 & 31 & 41 \\
\hline Lahana salatası (hazır) & 252 & 5 & 10 & 34 & 39 & 20 \\
\hline \multicolumn{7}{|l|}{ Karbonhidrattan zengin besinler } \\
\hline Beyaz ekmek & 97 & 9 & 2 & 44 & 70 & 73 \\
\hline Kepekli ekmek & 101 & 8 & 3 & 45 & 74 & 70 \\
\hline Tahıllı ekmek & 108 & 9 & 5 & 40 & 50 & 41 \\
\hline Patates (haşlanmış, soyulmuş) & 368 & 10 & 1 & 49 & 78 & 88 \\
\hline Beyaz pirinç & 203 & 5 & 1 & 56 & 72 & 58 \\
\hline Esmer pirinç & 148 & 5 & 2 & 53 & 72 & 45 \\
\hline Beyaz Makarna & 201 & 8 & 1 & 49 & 46 & 29 \\
\hline Esmer Makarna & 218 & 11 & 2 & 49 & 42 & 29 \\
\hline \multicolumn{7}{|l|}{ Proteinden zengin besinler } \\
\hline Yumurta (haşlanmış) & 160 & 21 & 18 & 1 & 0 & 23 \\
\hline Sığır biftek & 158 & 42 & 8 & 0 & 0 & 37 \\
\hline Tavuk (yağda kızartılmış, derili) & 94 & 23 & 17 & 0 & 0 & 19 \\
\hline Tavuk (firında kızartılmıs, derisiz) & 113 & 31 & 13 & 0 & 0 & 17 \\
\hline Beyaz balık & 333 & 56 & 1 & 0 & 0 & 43 \\
\hline Ton balığı (konserve, suda) & 239 & 48 & 5 & 0 & 0 & 26 \\
\hline Ton balığ (konserve, yağda, süzülmüş) & 135 & 24 & 15 & 2 & 0 & 16 \\
\hline Karides (haşlanmış, soyulmuş) & 235 & 48 & 4 & 2 & 0 & 21 \\
\hline Sosis (hot dog) & 95 & 14 & 19 & 3 & 28 & 16 \\
\hline Tofu & 227 & 27 & 11 & 7 & 15 & 21 \\
\hline Kuru fasulye (fırında pişmiş) & 351 & 16 & 2 & 39 & 44 & 88 \\
\hline Mercimek (domates soslu) & 253 & 19 & 5 & 29 & 37 & 42 \\
\hline Yer fistığı (tuzlu, kavrulmuş) & 38 & 10 & 20 & 5 & 14 & 15 \\
\hline Fistik ezmesi & 41 & 9 & 20 & 7 & 14 & 11 \\
\hline \multicolumn{7}{|l|}{ Yağdan zengin besinler } \\
\hline Ceviz & 35 & 6 & 23 & 1 & 0 & 5 \\
\hline Tereyağı & 33 & 0 & 27 & 0 & 0 & 2 \\
\hline Zeytinyağı & 27 & 0 & 27 & 0 & 0 & 3 \\
\hline \multicolumn{7}{|l|}{ İçecekler } \\
\hline Meyve suyu & 833 & 1 & 0 & 58 & 67 & 76 \\
\hline Soğuk çay (Icetea) & 622 & 0 & 0 & 59 & 59 & 69 \\
\hline Kola & 595 & 0 & 0 & 59 & 53 & 44 \\
\hline Bira (\%4.9 alkollü) & 671 & 2 & 0 & 13 & 66 & 20 \\
\hline Beyaz șarap (\%11 alkollü) & 362 & 1 & 0 & 1 & 0 & 3 \\
\hline
\end{tabular}


Formüllerde yer alan "n” değeri tüketilen besin sayısını, "Gİ” değeri a besininin glisemik indeksini, "İ $\dot{a}_{a}$ ” değeri a besininin insülin indeksini, "Karbonhidrat, değeri a besininin bir porsiyonunun içerdiği sindirilebilir karbonhidrat (toplam karbonhidrat-diyet posası) miktarını, "Enerji a besininin bir porsiyonunda bulunan enerji miktarını ve "Sılklık” değeri ise a besininin öğün içerisinde kaç kez tüketildiğini göstermektedir $(1,5,7)$.

Tablo 2'de bir kahvaltı öğününün Gİ ve İİ değerlerinin hesaplanması görülmektedir.

Bir besinin öğün içerisinde alındığındaki glukoz ve insülin yanıtı, tek başına alındığındaki glukoz ve insülin yanıtına göre farklı olabileceği için bazı araştırmacılar $(2,50)$ besinlerin Gì ve İ'ine göre öğünün Gİ ve İI’inin hesaplanmasının uygun olmayacağını düşünmektedir. Diğer taraftan, bazı araştırmacılar $(2,50)$ ise öğünün Gİ ve İI’inin besinlerin Gİ ve III'ine göre hesaplanmasinda herhangi bir sakınca olmadığını savunmaktadır. FAO/WHO Uzmanlar Komitesi bu şekilde hesaplanarak elde edilen Gİ değerleri ile aynı öğün tüketildikten sonra ölçülen glisemik yanıt arasında güçlü bir korelasyon olduğunu bildirmiştir (2). Tablo 3'de Bao ve arkadaşları (7) tarafından hazırlanan farklı ögünlerin tüketimi ile elde edilen öğünün Gİ ve İI değerleri görülmektedir.

\section{SONUÇ VE ÖNERİLER}

Obezite, diyabet ve kalp-damar hastalıkları gibi birçok kronik hastalıktan korunmanın ilk adımını, sağlıklı beslenme alışkanlıklarının kazandırılması ve fiziksel aktivite düzeyinin arttırılmasını kapsayan sağlıklı yaşam tarzı değişiklikleri oluşturmaktadır. Bu kapsamda bireylerin hızlı hazır ve enerji içeriği yüksek besinlerden, şekerli içeceklerinden uzak durmaya, doymuş ve trans yağ asitleri alımını azaltmaya, buna karşılık meyve, sebze, tam tahıl, kurubaklagil, az yağlı süt ürünleri ve balık tüketimini arttırmaya, düzenli kahvaltı ve fiziksel aktivite yapmaya özen göstermeleri gerekmektedir. Ayrıca, yapılan çalışmalarda, düşük Gİli öğünlerin açlık hissi ve besin alımını azaltarak obezite tedavisine yardımcı olabileceği ve düşük GI’li beslenme alışkanlıkları sayesinde uzun dönemde obezite, kalp-damar hastalıkları ve diyabet gibi hastalıkların önlenebileceği gösterilmiştir.

Diğer taraftan, düşük GI'li diyetlerin olası yararlı etkilerini postprandiyal glisemi ve insülinemiyi dengeleyerek yaptığı bilinmektedir. Son dönemde yapılan çalışmalarda ise Gİ'in tek başına postprandiyal insülinemiyi kontrol altına alamayacağı ve öğünün İI değerinin de göz önünde bulundurulmasının yararlı olacağına işaret etmektedir. Bununla birlikte, sadece 121 besinin İİ değerinin biliniyor olması, öğünün İ̇ değeri için yapılacak hesaplamaları oldukça

Tablo 2. Öğünün Gİ ve İI değerlerinin hesaplanması*

\begin{tabular}{|c|c|c|c|c|c|c|c|c|c|}
\hline Besinler & $\begin{array}{c}\text { Servis } \\
\text { ölçüsü (g } \\
\text { veya mL) }\end{array}$ & $\begin{array}{c}\text { Enerji } \\
(\mathrm{kJ})\end{array}$ & $\begin{array}{l}\text { Protein } \\
\text { (g) }\end{array}$ & $\begin{array}{l}\text { Yağ } \\
\text { (g) }\end{array}$ & $\begin{array}{c}\text { Sin } \\
\text { CHO (g) }\end{array}$ & $\begin{array}{c}\text { GI } \\
\text { (Besin) }\end{array}$ & $\begin{array}{c}\text { Gí } \\
\text { (Öğün) }\end{array}$ & $\begin{array}{c}\dot{\mathbf{I I}} \\
(\text { Besin) }\end{array}$ & $\begin{array}{c}\text { İİ } \\
\text { (Öğün) }\end{array}$ \\
\hline $\begin{array}{l}1 \text { su bardağı } \\
\text { tam yağlı süt }\end{array}$ & 200 & 543 & 6.0 & 7.6 & 9.2 & 31 & $\begin{array}{c}6.9 \\
(31 \times 9.2 / 41.3)\end{array}$ & 24 & $\begin{array}{c}8.4 \\
(24 \times 543 / 1549)\end{array}$ \\
\hline $\begin{array}{l}1 \text { adet } \\
\text { haşlanmış yumurta }\end{array}$ & 50 & 313 & 6.6 & 5.6 & 0.3 & 0 & $\begin{array}{c}0 \\
(0 \times 0.3 / 41.3)\end{array}$ & 23 & $\begin{array}{c}4.6 \\
(23 \times 313 / 1549)\end{array}$ \\
\hline 1 küçük boy elma & 100 & 230 & 0.2 & 0.0 & 13.3 & 36 & $\begin{array}{c}11.6 \\
(36 \times 13.3 / 41.3)\end{array}$ & 43 & $\begin{array}{c}6.4 \\
(43 \times 230 / 1549)\end{array}$ \\
\hline $\begin{array}{l}2 \text { ince dilim } \\
\text { tahıllı ekmek }\end{array}$ & 50 & 463 & 4.2 & 2.3 & 18.5 & 50 & $\begin{array}{c}22.4 \\
(50 \times 18.5 / 41.3)\end{array}$ & 41 & $\begin{array}{c}12.3 \\
(41 \times 463 / 1549)\end{array}$ \\
\hline Toplam öğün & & 1549 & 17 & 15.5 & 41.3 & & 41 & & 32 \\
\hline
\end{tabular}

*Yazarlar tarafindan hesaplanmıştır.

Sin CHO: Sindirilebilir karbonhidrat, GI:: Glisemik indeks, İI: Besin insülin indeksi

Bu öğünün GY’ü $[(31 \times 9.2)+(0 \times 0.3)+(36 \times 13.3)+(50 \times 18.5)] / 100=17$ 'dir.

Bu öğünün IY’’ü ise $[(24 \times 543)+(23 \times 313)+(43 \times 230)+(41 \times 463)] / 100=\% 491$ 'dir. 
Tablo 3. Farklı glisemik indeks ve insülin indeksli öğün örnekleri (7)

\begin{tabular}{|c|c|c|c|c|c|c|c|c|}
\hline Besin grupları & $\begin{array}{l}\text { Servis ölçüsü } \\
\text { (g veya mL) }\end{array}$ & $\begin{array}{c}\text { Enerji } \\
(\mathrm{kJ})\end{array}$ & $\begin{array}{c}\text { Enerji oranı } \\
(\%)\end{array}$ & $\begin{array}{l}\text { Protein } \\
\text { (g) }\end{array}$ & $\begin{array}{l}\text { Yağ } \\
\text { (g) }\end{array}$ & $\begin{array}{c}\text { Sin CHO } \\
(\mathrm{g})\end{array}$ & Gí & İİ \\
\hline \multicolumn{9}{|l|}{ Referans besin } \\
\hline Beyaz ekmek & 193 & 2000 & 100 & 19.4 & 4.8 & 93.4 & 70 & 100 \\
\hline \multicolumn{9}{|l|}{ Kahvaltı } \\
\hline \multicolumn{9}{|l|}{ Menü 1} \\
\hline Tahıllı ekmek & 77.7 & 786 & 39.3 & 12.0 & 5.4 & 23.2 & 36 & 71 \\
\hline Fistık ezmesi & 25.0 & 668 & 33.4 & 5.8 & 13.4 & 4.4 & 14 & 15 \\
\hline Tam yağll süt & 200 & 546 & 27.3 & 6.8 & 7.2 & 9.6 & 31 & 33 \\
\hline Toplam öğün & 302.7 & 2000 & 100 & 24.6 & 26.0 & 37.2 & 32 & 42 \\
\hline \multicolumn{9}{|l|}{ Menü 2} \\
\hline Kavun & 100 & 140 & 7 & 0.7 & 0.3 & 6.5 & 62 & 127 \\
\hline Muz & 98 & 353 & 17.7 & 1.7 & 0.1 & 19.6 & 52 & 81 \\
\hline Yoğurt & 300 & 1167 & 58.3 & 15.9 & 2.7 & 44.1 & 31 & 115 \\
\hline Elma suyu & 200 & 340 & 17 & 0.2 & 0.0 & 20.2 & 39 & 64 \\
\hline Toplam öğün & 698 & 2000 & 100 & 18.5 & 3.1 & 90.4 & 40 & 101 \\
\hline \multicolumn{9}{|l|}{ Ara öğün } \\
\hline \multicolumn{9}{|l|}{ Menü 3} \\
\hline Ceviz & 44 & 1276 & 63.8 & 7.2 & 29.6 & 1.6 & N/A & 7 \\
\hline Kuru üzüm & 28.3 & 396 & 19.8 & 0.7 & 0.1 & 22.6 & 64 & 42 \\
\hline Havuç suyu & 250 & 328 & 16.4 & 2.0 & 0.3 & 13.5 & 47 & 56 \\
\hline Toplam öğün & 322.3 & 2000 & 100 & 9.9 & 30.0 & 37.7 & 55 & 22 \\
\hline \multicolumn{9}{|l|}{ Menü 4} \\
\hline Ahududu reçeli & 30 & 351 & 17.6 & 0.0 & 0.0 & 20.4 & 51 & 85 \\
\hline Kruvasan & 85 & 1304 & 65.2 & 7.1 & 15.0 & 36.4 & 67 & 79 \\
\hline Soğuk çay & 214 & 345 & 17.2 & 0.0 & 0.0 & 20.6 & 59 & 95 \\
\hline Toplam öğün & 329 & 2000 & 100 & 7.1 & 15.0 & 77.4 & 61 & 83 \\
\hline \multicolumn{9}{|l|}{ Öğle yemeği } \\
\hline \multicolumn{9}{|l|}{ Menü 5} \\
\hline Firında tavuk & 75 & 662 & 33.1 & 20.2 & 8.6 & 0.0 & N/A & 23 \\
\hline Avokado & 40 & 356 & 17.8 & 0.8 & 9.0 & 0.2 & N/A & 6 \\
\hline Tahıllı ekmek & 97.1 & 982 & 49.1 & 15.1 & 6.8 & 28.9 & 36 & 71 \\
\hline Toplam öğün & 212.1 & 2000 & 100 & 36.1 & 24.4 & 29.1 & 36 & 44 \\
\hline \multicolumn{9}{|l|}{ Akşam yemeği } \\
\hline Menü 6 & & & & & & & & \\
\hline Ton balığı & 110 & 815 & 40.8 & 19.6 & 12.3 & 1.8 & N/A & 22 \\
\hline Beyaz pirinç & 221.7 & 981 & 49.0 & 4.3 & 0.0 & 52.4 & 75 & 79 \\
\hline Misir & 45 & 204 & 10.2 & 1.3 & 0.7 & 8.7 & 47 & 53 \\
\hline Toplam öğün & 376.7 & 2000 & 100 & 25.2 & 13 & 62.9 & 69 & 53 \\
\hline Kahvaltı & & & & & & & & \\
\hline Menü 7 & & & & & & & & \\
\hline Tahll gevreği & 245 & 1500 & 75 & 17.2 & 4.6 & 61.0 & 30 & 32 \\
\hline Elma suyu & 294 & 500 & 25 & 0.3 & 0.0 & 29.7 & 39 & 64 \\
\hline Toplam öğün & 539 & 2000 & 100 & 17.5 & 4.6 & 90.7 & 33 & 40 \\
\hline Menü 8 & & & & & & & & \\
\hline Haşlanmış yumurta & 159 & 1000 & 50 & 19.6 & 17.8 & 0.5 & N/A & 31 \\
\hline Kepekli ekmek & 101 & 1000 & 50 & 7.6 & 2.6 & 38.9 & 68 & 96 \\
\hline Toplam öğün & 260 & 2000 & 100 & 27.2 & 20.4 & 39.4 & 67 & 64 \\
\hline Ara öğün & & & & & & & & \\
\hline Menü 9 & & & & & & & & \\
\hline Muz & 279 & 1000 & 50 & 4.8 & 0.3 & 55.5 & 52 & 81 \\
\hline Tam yağlı süt & 352 & 1000 & 50 & 12.0 & 13.7 & 16.5 & 31 & 33 \\
\hline Toplam öğün & 631 & 2000 & 100 & 16.8 & 14.0 & 72.0 & 47 & 57 \\
\hline Menü 10 & & & & & & & & \\
\hline Kurabiye & 49 & 1000 & 50 & 2.7 & 10.4 & 17.3 & 62 & 92 \\
\hline Dondurma & 123 & 1000 & 50 & 6.5 & 12.3 & 27.1 & 50 & 89 \\
\hline Toplam öğün & 172 & 2000 & 100 & 9.2 & 22.7 & 44.4 & 55 & 91 \\
\hline Öğle yemeği & & & & & & & & \\
\hline Menü 11 & & & & & & & & \\
\hline Pizza & 90 & 1000 & 50 & 12.4 & 7.6 & 30.2 & 60 & 64 \\
\hline Kola & 583 & 1000 & 50 & 0.0 & 0.0 & 61.8 & 53 & 60 \\
\hline Toplam öğün & 673 & 2000 & 100 & 12.5 & 7.6 & 92.0 & 55 & 62 \\
\hline Akşam yemeği & & & & & & & & \\
\hline Menü 12 & & & & & & & & \\
\hline Makarna & 201 & 1000 & 50 & 7.8 & 8.0 & 45.6 & 44 & 40 \\
\hline Mercimek & 253 & 1000 & 50 & 19.4 & 4.6 & 17.7 & 37 & 58 \\
\hline Toplam öğün & 454 & 2000 & 100 & 27.2 & 12.6 & 63.3 & 42 & 49 \\
\hline Menü 13 & & & & & & & & \\
\hline Sığır biftek & 158 & 1000 & 50 & 42 & 7.7 & 0.0 & $\mathrm{~N} / \mathrm{A}$ & 51 \\
\hline Haşlanmış patates & 368 & 1000 & 50 & 10.0 & 1.0 & 39.8 & 77 & 121 \\
\hline Toplam ögün & 526 & 2000 & 100 & 52.0 & 8.7 & 39.8 & 77 & 86 \\
\hline
\end{tabular}


sınırlamaktadır. Bu nedenle, besinlerin İİ değerinin belirlendiği daha fazla çalışmaya gereksinme vardır. Ayrıca, yaygin olarak kullanılan sebzeler, meyveler, tahıllar, içecekler vb. gibi besinler için ülkelere özgü Gİ ve İI değerlerini içeren tabloların geliştirilmesi yararlı olacaktır.

Bir ögün düşük Gİli olmasına rağmen, yüksek İI’li olabilmektedir ve bunun aksi de mümkündür. Bu nedenle, öğün planlaması yaparken hem düşük Gİli hem de düşük İI’li olmasına özen gösterilerek öğün sonrası yaşanacak hiperglisemi ve hiperinsülinemi önlenebilir. $\mathrm{Bu}$ sayede, özellikle obez bireylerde hem açlık hissi geciktirilerek iştah kontrolüne yardımcı olunabilecek hem de insülin direnci gelişimi önlenebilecek veya süreç geciktirilebilecektir. Ayrıca, tip 2 diyabetli bireylerde glisemik kontrolün sağlanmasınayardımcıolacağıgibi,komplikasyonların oluşum sürecini de erteleyebilecek ve uzatacaktır.

Çıkar çatışması - Conflict of interest: Yazarlar çıkar çatışması olmadığını beyan ederler. - The authors declare that they have no conflict of interest.

\section{KAYNAKLAR}

1. Bao J, Atkinson F, Petocz P, Willett WC, Brand-Miller JC. Prediction of postprandial glycemia and insulinemia in lean, young, healthy adults: Glycemic load compared with carbohydrate content alone. Am J Clin Nutr 2011;93:984-996.

2. Özel HG. Glisemik indeks ve yük: Gerçekler ve çelişkiler (Eds: Tayfur M, Ayhan NY). Beslenme ve Diyetetik Güncel Konular - II. 1. Baskı. Hatiboğlu Yayınevi, Ankara, 2015, s. 109-136.

3. Kong KL, Hendrich S. Glycemic index, insulinemic index, and satiety index of kefir. J Am Coll Nutr 2012;31:280287.

4. Joint FAO/WHO Expert Consultation on Carbohydrates in Human Nutrition (1998: Rome, Italy) \& World Health Organization (1998). Carbohydrates in human nutrition: Report of a joint FAO/WHO expert consultation, Rome, 14-18 April 1997. Rome : FAO.

5. Nimptsch K, Brand-Miller JC, Franz M, Sampson L, Willett WC, Giovannucci E. Dietary insulin index and insulin load in relation to biomarkers of glycemic control, plasma lipids, and inflammation markers. Am J Clin Nutr 2011;94:182-190.

6. Holt SH, Miller JC, Petocz P. An insulin index of foods: the insulin demand generated by $1000-\mathrm{kJ}$ portions of common foods. Am J Clin Nutr 1997;66:1264-1276.

7. Bao J, de Jong V, Atkinson F, Petocz P, Brand-Miller JC. Food insulin index: Physiologic basis for predicting insulin demand evoked by composite meals. Am J Clin Nutr 2009;90:986-992.

8. Jakubowicz D, Wainstein J, Ahrén B, Bar-Dayan Y, Landau Z, Rabinovitz HR, et al. High-energy breakfast with lowenergy dinner decreases overall daily hyperglycaemia in type 2 diabetic patients: A randomised clinical trial. Diabetologia 2015;58:912-919.

9. Kong AP, Chan RS, Nelson EA, Chan JC. Role of lowglycemic index diet in management of childhood obesity. Obes Rev 2011;12:492-498.

10. Rouhani MH, Kelishadi R, Hashemipour M, Esmaillzadeh A, Azadbakht L. Glycemic index, glycemic load and childhood obesity: A systematic review. Adv Biomed Res 2014;3:47-54.

11. Dickinson S, Hancock DP, Petocz P, Ceriello A, BrandMiller J. High-glycemic index carbohydrate increases nuclear factor-kappaB activation in mononuclear cells of young, lean healthy subjects. Am J Clin Nutr 2008;87:1188-1193.

12. Nilsson AC, Ostman EM, Holst JJ, Bjorck IM. Including indigestible carbohydrates in the evening meal of healthy subjects improves glucose tolerance, lowers inflammatory markers, and increases satiety after a subsequent standardized breakfast. J Nutr 2008;138:732739.

13. Pawlak DB, Kushner JA, Ludwig DS. Effects of dietary glycaemic index on adiposity, glucose homoeostasis, and plasma lipids in animals. Lancet 2004;364:778-785.

14. Isken F, Klaus S, Petzke KJ, Loddenkemper C, Pfeiffer AF, Weickert MO. Impairment of fat oxidation under high- vs. low-glycemic index diet occurs before the development of an obese phenotype. Am J Physiol Endocrinol Metab 2010;298:E287-295.

15. Joslowski G, Goletzke J, Cheng G, Günther AL, Bao J, Brand-Miller JC, et al. Prospective associations of dietary insulin demand, glycemic index, and glycemic load during puberty with body composition in young adulthood. Int J Obes (Lond) 2012;36:1463-1471.

16. Chaput JP, Tremblay A, Rimm EB, Bouchard C, Ludwig DS. A novel interaction between dietary composition and insulin secretion: Effects on weight gain in the Quebec Family Study. Am J Clin Nutr 2008;87:303-309.

17. Kaaks R, Lukanova A. Energy balance and cancer: the role of insulin and insulin-like growth factor-I. Proc Nutr Soc 2001;60:91-106.

18. Aston LM, Stokes CS, Jebb SA. No effect of a diet with a reduced glycaemic index on satiety, energy intake and body weight in overweight and obese women. Int J Obes 
(Lond) 2008;32:160-165.

19. Krog-Mikkelsen I, Sloth B, Dimitrov D, Tetens I, Björck I, Flint A, et al. A low glycemic index diet does not affect postprandial energy metabolism but decreases postprandial insulinemia and increases fullness ratings in healthy women. J Nutr 2011;141:1679-1684.

20. Zakrzewski JK, Stevenson EJ, Tolfrey K. Effect of breakfast glycemic index on metabolic responses during rest and exercise in overweight and non-overweight adolescent girls. Eur J Clin Nutr 2012;66:436-442.

21. Çelik H. Eksojen Obez Adolesanların Düşük ve Yüksek Glisemik İndeksli Kahvaltıya Yanıtının Serum Glikoz, Insülin, C-Peptid ve Lipid Düzeyleri ile Değerlendirilmesi (Uzmanlık Tezi). Edirne: Trakya Üniversitesi; 2007.

22. Reynolds RC, Stockmann KS, Atkinson FS, Denyer GS, Brand-Miller JC. Effect of the glycemic index of carbohydrates on day-long $(10 \mathrm{~h})$ profiles of plasma glucose, insulin, cholecystokinin and ghrelin. Eur J Clin Nutr 2009;63:872-878.

23. Stevenson EJ, Astbury NM, Simpson EJ, Taylor MA, Macdonald IA. Fat oxidation during exercise and satiety during recovery are increased following a lowglycemic index breakfast in sedentary women. J Nutr 2009;139:890-897.

24. Morgan LM, Shi JW, Hampton SM, Frost G. Effect of meal timing and glycaemic index on glucose control and insulin secretion in healthy volunteers. Br J Nutr 2012;108:1286-1291.

25. Burton-Freeman BM, Keim NL. Glycemic index, cholecystokinin, satiety and disinhibition: Is there an unappreciated paradox for overweight women? Int J Obes (Lond) 2008;32:1647-1654.

26. Liu AG, Most MM, Brashear MM, Johnson WD, Cefalu WT, Greenway FL. Reducing the glycemic index or carbohydrate content of mixed meals reduces postprandial glycemia and insulinemia over the entire day but does not affect satiety. Diabetes Care 2012;35:1633-1637.

27. Lennerz BS, Alsop DC, Holsen LM, Stern E, Rojas R, Ebbeling CB, et al. Effects of dietary glycemic index on brain regions related to reward and craving in men. Am J Clin Nutr 2013;98:641-647.

28. Solomon TP, Haus JM, Kelly KR, Cook MD, Filion J, Rocco M, et al. A low-glycemic index diet combined with exercise reduces insulin resistance, postprandial hyperinsulinemia, and glucose-dependentinsulinotropic polypeptide responses in obese, prediabetic humans. Am J Clin Nutr 2010;92:1359-1368.

29. Milton JE, Sananthanan CS, Patterson M, Ghatei MA, Bloom SR, Frost GS. Glucagon-like peptide-1 (7-36) amide response to low versus high glycaemic index preloads in overweight subjects with and without type II diabetes mellitus. Eur J Clin Nutr 2007;61:1364-1372.

30. Brownley KA, Heymen S, Hinderliter AL, Galanko J, Macintosh B. Low-glycemic load decreases postprandial insulin and glucose and increases postprandial ghrelin in white but not black women. J Nutr 2012;142:12401245.

31. Runchey SS, Pollak MN, Valsta LM, Coronado GD, Schwarz Y, Breymeyer KL, et al. Glycemic load effect on fasting and post-prandial serum glucose, insulin, IGF-1 and IGFBP-3 in a randomized, controlled feeding study. Eur J Clin Nutr 2012;66:1146-1152.

32. Runchey SS, Valsta LM, Schwarz Y, Wang C, Song X, Lampe JW, et al. Effect of low- and high-glycemic load on circulating incretins in a randomized clinical trial. Metabolism 2013;62:188-195.

33. Ball SD, Keller KR, Moyer-Mileur LJ, Ding YW, Donaldson D, Jackson WD. Prolongation of satiety after low versus moderately high glycemic index meals in obese adolescents. Pediatrics 2003;111:488-494.

34. Cooper SB, Bandelow S, Nute ML, Morris JG, Nevill ME. Breakfast glycaemic index and exercise: Combined effects on adolescents' cognition. Physiol Behav 2015;139:104-111.

35. Ludwig DS, Majzoub JA, Al-Zahrani A, Dallal GE, Blanco I, Roberts SB. High glycemic index foods, overeating, and obesity. Pediatrics 1999;103:E26.

36. Mirza NM, Klein CJ, Palmer MG, McCarter R, He J, Ebbeling CB, et al. Effects of high and low glycemic load meals on energy intake, satiety and hunger in obese Hispanic-American youth. Int J Pediatr Obes 2011;6:e523-31.

37. Ordu TY. Beden Kütle İndeksleri Farklı Yetişkin Bireylerde Öğünün Glisemik Yükünün Kan Şekeri Üzerindeki Etkisi (Yüksek Lisans Tezi). Ankara: Hacettepe Üniversitesi; 2011.

38. Bell KJ, Bao J, Petocz P, Colagiuri S, Brand-Miller JC. Validation of the food insulin index in lean, young, healthy individuals, and type 2 diabetes in the context of mixed meals: An acute randomized crossover trial. Am J Clin Nutr 2015;102:801-806.

39. Augustin LS, Kendall CW, Jenkins DJ, Willett WC, Astrup A, Barclay AW, et al. Glycemic index, glycemic load and glycemic response: An International Scientific Consensus Summit from the International Carbohydrate Quality Consortium (ICQC). Nutr Metab Cardiovasc Dis 2015;25:795-815.

40. McMillan-Price J, Brand-Miller J. Low-glycaemic index diets and body weight regulation. Int J Obes 2006;30:S40-S46.

41. Joslowski G, Halim J, Goletzke J, Gow M, Ho M, Louie JC, et al. Dietary glycemic load, insulin load, and weight loss in obese, insulin resistant adolescents: RESIST study. 
Clin Nutr 2015;34:89-94.

42. Juanola-Falgarona M, Salas-Salvadó J, Ibarrola-Jurado N, Rabassa-Soler A, Díaz-López A, Guasch-Ferré M, et al. Effect of the glycemic index of the diet on weight loss, modulation of satiety, inflammation, and other metabolic risk factors: A randomized controlled trial. Am J Clin Nutr 2014;100:27-35.

43. Batista SMM, Moreira EAM, Fiates GMR, de Assis MAA, Teixeira E. Effect of low glycaemic index diets on satiety. Br Food J 2014;116:1233-1246.

44. Chang KT, Lampe JW, Schwarz Y, Breymeyer KL, Noar KA, Song X, et al. Low glycemic load experimental diet more satiating than high glycemic load diet. Nutr Cancer 2012;64:666-673.

45. Munsters MJ, Geraedts MC, Saris WH. Effects of different protein and glycemic index diets on metabolic profiles and substrate partitioning in lean healthy males. Appl Physiol Nutr Metab 2013;38:1107-1114.

46. Probst A, Humpeler S, Heinzl H, Blasche G, Ekmekcioglu C. Short-term effect of macronutrient composition and glycemic index of a yoghurt breakfast on satiety and mood in healthy young men. Forsch Komplementmed 2012;19:247-251.

47. Rosen LA, Ostman EM, Bjorck IM. Postprandial glycemia, insulinemia, and satiety responses in healthy subjects after whole grain rye bread made from different rye varieties. J Agricl Food Chem 2011;59:12149-12154.

48. Simmons AL, Miller CK, Clinton SK, Vodovotz Y. A comparison of satiety, glycemic index, and insulinemic index of wheat-derived soft pretzels with or without soy. Food Funct 2011;2:678-683.

49. Gonzalez-Anton C, Rico MC, Sanchez-Rodriguez E, RuizLopez MD, Gil A, Mesa MD. Glycemic responses, appetite ratings and gastrointestinal hormone responses of most common breads consumed in Spain: A randomized control trial in healthy humans. Nutrients 2015;7:40334053.

50. Brouns F, Bjorck I, Frayn KN, Gibbs AL, Lang V, Slama $G$, et al. Glycaemic index methodology. Nutr Res Rev 2005;18:145-171. 